/cpr

\title{
Private Rental Housing: The Canadian Experience
}

\author{
John R. Miron \\ [Paper first received, January 1994; in final form, July 1994]
}

\begin{abstract}
Summary. Almost three persons in ten in Canada currently rent their accommodation in the private sector: whether in the conventional or non-conventional rental stock. Over the past half-century, there have also been major improvements in financing and in the liquidity of the rental stock-widely thought to be important in attracting investment in rental housing-and all levels of Canadian government have experimented with a broad range of housing subsidies and initiatives. In this paper, outcomes in private markets for rental housing are seen as a consequence of a shift in demand or supply that may itself reflect a policy initiative. This paper examines two markets: a market for rental housing stock (whose outcomes include property prices, new construction, renovation, demolitions, conversions and other alterations) and a market for rental accommodation (whose outcomes include rents, vacancy rates, usage and the assignment of households to dwellings). The paper reviews basic data on market outcomes in Canada since the Second World War. It then discusses important shifts in the demand for, and supply of, rental accommodation and describes major policy initiatives that may have affected these.
\end{abstract}

As Britain considers how to spur the development of private rental housing, the Canadian experience should be of interest. Canada has a large stock of for-profit private rental housing. Major innovations in financing and improvements in liquidity of the rental stock over the past half-century have made such investments more attractive. Canada also has a substantial stock of social housing-public housing, non-profit housing, and non-equity cooperatives - that competes with the private rental sector for tenants. The Canadian public policy experience (from housing subsidies to rental market regulation), varying as it does among ten provinces in an economic union, constitutes interesting, if informal, social experimentation. And, federal-provincial-municipal relations provide insights into the feasibility of decentralisation in housing policy delivery.

This paper has two objectives. One is to view the Canadian experience as a set of market outcomes, and to show that this perspective is useful in examining the relevant supply, demand and policy factors. Much of the housing that Canadians occupy is provided through a complex of markets that includes housing finance, residential land, building materials, construction labour, residential utilities and maintenance services. Competition drives these markets towards equilibria in market rents across both geographical space and quality levels (see Sweeney, 1974; Kanemoto, 1990; and Weber and Wiesmeth, 1990), equilibria among the prices of alternative tenures, and equilibria in 
price and return among financial and land assets. Public policy initiatives are often introduced to alter the outcome in a particular market (e.g. to increase the incidence of home ownership); however, these initiatives also affect other sectors through the equilibria among markets (e.g. the loss of rent to landlords that occurs because consumers switch from renting to owning).

The second is to review policy initiatives in order to show both their breadth and, at the same time, the simplistic view that these programmes have taken of the complex of housing markets. In the context of global competition, some policy-makers have become more aware of the benefits (or necessity) of efficient markets generally, and of the hidden costs of regulation and subsidies. However, only some of the Canadian initiatives can be thought to have enhanced market efficiency. Why were the other initiatives undertaken? Were they ill-advised? The paper reviews basic data on rental housing market outcomes in Canada since the Second World War. It discusses important shifts in the demand for, and supply of, rental accommodation and evaluates major policy initiatives that have affected these.

\section{Rental Market Outcomes}

Any change in outcome in a private market for rental housing can be thought to result from shifts in demand or supply, including shifts that may result from a policy initiative. To begin, let us briefly characterise post-war changes in rental housing outcomes. Let us leave aside for the moment consideration of public policy initiatives-these are discussed later in this paper-and now examine significant outcomes in the for-profit markets for rental stock and rental accommodation, and in the related market for residential finance. This section of the paper emphasises two markets: a market for rental housing stock (whose outcomes include property prices, new construction, renovation, demolitions, conversions and other alterations) and a market for rental accommodation (whose outcomes include rents, vacancy rates, usage and the assignment of households to dwellings): an approach also used in Fallis (1993), Smith et al. (1988), Olsen (1987), and Quigley (1979).

Census counts of private households measure one important outcome in the market for rental accommodation. ${ }^{1}$ Between 1941 and 1991, the number of renter households increased quickly; see Table $1 .^{2}$ By 1991, about three persons in ten in Canada lived in households that rented their accommodation in the private, forprofit, sector. It is difficult to be precise since the best available data-quinquennial census counts - include persons living in the conventional and non-conventional rental stock, ${ }^{3}$ but do not identify whether rental units are for-profit. Further, census counts of renters do not include tenants in collective buildings (large rooming houses, residency hotels and other institutional accommodation), individual rooms in owner-occupied dwellings that are rented out to lodgers, or owned homes on rented land (in Canada, these are mainly mobile homes). Whatever their shortcomings, census counts do show a declining incidence of renting. In the 1991 Census, 37 per cent of households were renters, down from 43 per cent in 1941. ${ }^{4}$ Only during the Great Apartment Boom (which began in the early 1960s, peaked between 1968 and 1973, and ended abruptly thereafter) did the incidence of renting actually rise.

Another outcome in the market for rental accommodation is rent paid (see Table 2). From 1951 to 1991 , gross rents paid by residential tenants increased fortyfold. The increase was substantial when viewed as a share of Personal Consumer Expenditure (PCE). Being mindful that housing expenditure is less volatile than other consumer expenditures and hence falls as a percentage of PCE in an economic expansion (and rises during a recession), there was overall an upward trend over time; gross rents were 5.3 per cent of PCE in 1991, up from just 3.5 per cent in 1951. This overall increase, while substantial, can also be misleading. 
Table 1. Dwellings by category and tenure (excluding households abroad), Canada, 1951-91

\begin{tabular}{lcccrr}
\hline & \multicolumn{5}{c}{ Thousands of dwellings } \\
\cline { 2 - 6 } Dwellings occupied (by usual residents) & 1951 & 1961 & 1971 & 1981 & 1991 \\
\hline Private dwellings & 3409 & 4555 & 6035 & 8282 & 10018 \\
Owner-occupied & 2237 & 3006 & 3612 & 5106 & 6273 \\
Rented & 1172 & 1549 & 2393 & 3131 & 3719 \\
On reserve & - & - & 30 & 44 & 27 \\
Collective dwellings & 12 & 22 & 18 & 17 & 21 \\
\hline
\end{tabular}

Notes:-indicates data not available. 1991 Census count above underestimates households on Indian reserves and Indian settlements. Prior to 1986, households on reserves are not reported in published data; estimates are calculated from Enumeration Area (short form) housing files (since 1971 ) by totaling dwelling s by tenure on reserve EAs, and backing thes e estimates out of published counts of owner-occupied and rented dwellings.

Source: Computed from published reports of the decennial censuses of Canada since 1951.

-During this period, the expenditures of home-owners rose even faster. Imputed rents for home-owners were 14 per cent of PCE in 1991 up from just 7 per cent in 1951. By 1991, the average annual imputed rent of a home-owner was 60 per cent higher than the average rent paid by a tenant, whereas the two had been similar just 40 years before (see Table 2).

- The increase in rents fluctuated over this period. In the early 1950 s, residential rents rose quickly, a consequence of economic expansion, inflation generated as a result of the Korean war, and the end of wartime rent control (see Figure 1). During the recession of 1957-62, average rents increased slowly. With the economic boom of the 1960s, rents rose more quickly, and then accelerated during the oil crises of the 1970s. The recession of 1981-82 slowed the rate of increase. In most cities, rents increased again sharply in the booming late $1980 \mathrm{~s}$ before softening in the most recent recession.

A third outcome in the market for rental accommodation is the vacancy rate. The vacancy rate is the proportion of rental units (in rental buildings of six units or more) available to be let at a particular date: a unit being deemed available if presently unoccupied (and available for occupancy immediately) or occupied but with the lease ending presently but not yet renewed. Vacancy rates (measured only for the conventional stock) have been volatile; see Figure 2. The vacancy rate in Calgary, a city whose economic prospects are closely tied to the oil and gas industry, has fluctuated markedly. The effect of the Great Apartment Boom that added so much new conventional rental stock nationally can also be seen in Figure 2.

A fourth outcome of the market for rental accommodation is the gross yield on rental buildings. Gross yield is estimated by dividing the sum of gross rents paid annually in Canada by the estimated asset value of the rental stock in that year: see Figure $3 .^{5}$ Gross yield declined overall from almost 14 per cent in 1961 to under 10 per cent by 1974 (at the end of the Great Apartment Boom), and increased slowly thereafter to reach 12 per cent by 1991. Such yields, which since the early 1970 s have rarely exceeded the current mortgage rate, raise questions about the attractiveness of investment in rental housing.

Turning now to the market for rental housing stock, an important outcome is the volume of net additions to the stock. The ease of switching dwelling occupancy between tenures makes it difficult to measure the annual net production of new rental stock. An apartment building might be planned as a rental project but, during construction, the 
Table 2. Consumer income and its disposition, showing gross rent per renter household and imputed rent per owner-occupier household, in current dollars, Canada, 1951-91

\begin{tabular}{lrrrrr}
\hline & 1951 & 1961 & 1971 & 1981 & 1991 \\
\hline Personal income and its disposition (\$ bn) & & & & & \\
Personal income & 16.9 & 30.6 & 75.3 & 293.2 & 607.4 \\
Personal disposable income & 15.6 & 27.4 & 61.1 & 237.7 & 467.2 \\
Personal consumer expenditure & 14.0 & 26.2 & 56.3 & 196.2 & 410.4 \\
Accommodation & 2.0 & 4.9 & 11.0 & 40.7 & 95.8 \\
Imputed rent & 1.0 & 2.7 & 6.0 & 23.6 & 58.1 \\
Gross rent paid & 0.5 & 1.1 & 3.0 & 9.1 & 21.6 \\
Annual expenditure per household (\$) & & & & & \\
Gross rent paid per renter household & 415 & 737 & 1249 & 2899 & 5816 \\
Imputed rent per owner-occ upier household & 440 & 882 & 1674 & 4623 & 9263 \\
\hline
\end{tabular}

Sources: Personal income: Statistics Canada's National Income and Expenditure Accounts: Annual Estimates; Annual expenditure calculated by dividing appropr iate rent (paid or imputed) by census count of households (renters or owners) shown in Table 1.

developer chooses instead to market it as owner-occupied condominiums. In other cases, a developer might choose to syndicate a rental building as a condominium; making it appear to be intended for owner-occupancy. Nonetheless, there are two important indicators of changing outcomes in the market for rental housing stock.

- The Great Apartment Boom was unprecedented in Canada. See Figure 4 and Smith (1983, p. 63). Much of the new stock in this period was built by the for-profit sector, although the public sector also found high-rise construction an efficient way to create social housing.

- Accompanying this new construction was much investment in alterations and improvements to the existing stock (see Table 3). From 1951 through the mid 1970s, new construction made up at least two-thirds of residential gross fixed capital formation.

- However, since the early 1970 s, new construction of conventional rental housing stock has dwindled (see Smith, 1983, p. 60 ), and expenditures on alterations and improvements as a percentage of the aggregate value of the existent housing stock have climbed.

\section{The Demand for Rental Housing}

Canada experienced brisk population growth over the past half-century. The fertility slump of the 1920s and 1930s gave way after the Second World War to an unprecedented baby boom, which in turn gave way to the baby bust beginning in the 1960s. However, substantial immigration combined with a burgeoning population in the childbearing age groups and greater life expectancy to increase the population of Canada from 18 million in 1961 to over 27 million in 1991 (see Table 4).

The baby boom caused the population aged 15-29 to peak near 1976-the progression of the baby boom cohort into the family formation ages is mirrored in rising census counts of families (see Table 4). ${ }^{6}$ At the same time, the baby bust and an accompanying decline in marriage rates helped ameliorate this increase, and led to more non-family persons.

Changes in the incomes of individuals and families are important in understanding the demand for rental housing. During each post-war economic boom, the average nominal incomes of individuals rose substantially. Through the first half of the 1970s, the average incomes of Canadian men, women and families generally increased faster than consumer prices; hence, real incomes rose. From 1977 to 1984 , how- 


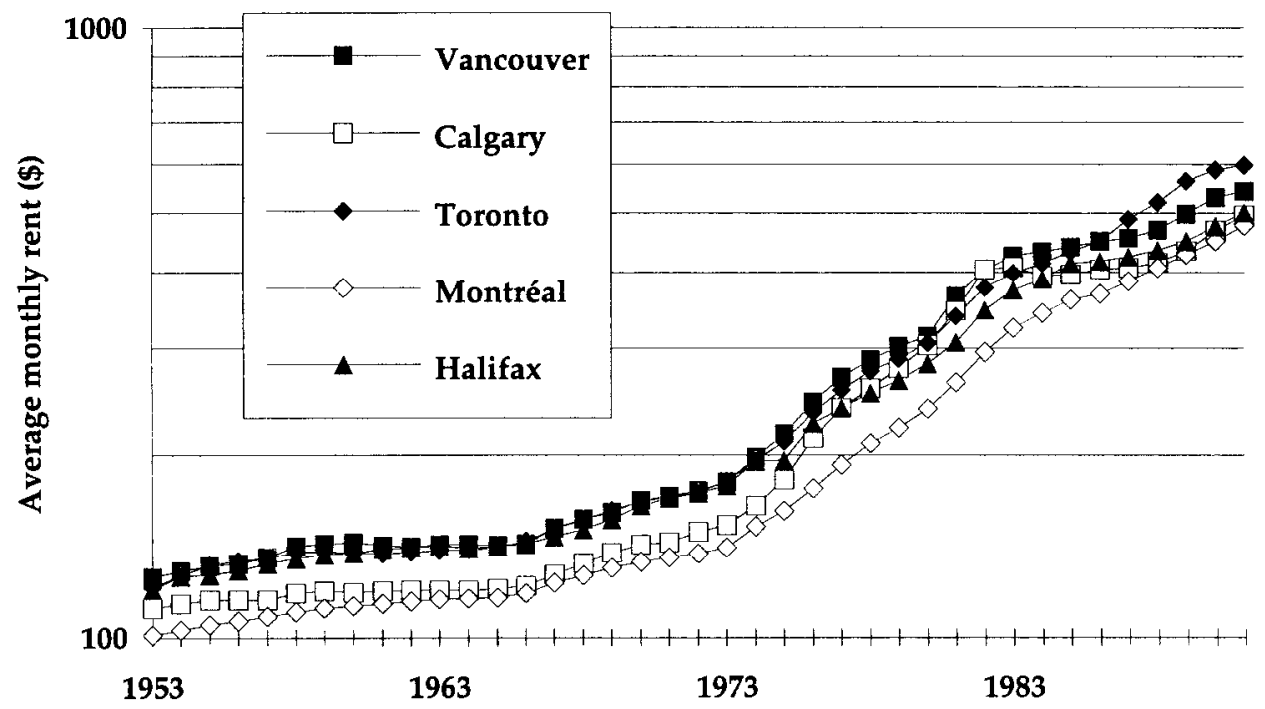

Figure 1. Average gross rent (including utilities and services) for rented dwelling of standard quality, selected Canadian metropolitan areas, 1953-91. Source: 1971 average rents estimated from Survey of Housing Units public-use sample. Other years calculated using annual percentage change in rent component of city CPI.

ever, the average incomes of individual males failed to keep pace with inflation; losses that were only partially recouped during the late $1980 \mathrm{~s}$ boom that preceded the most recent recession. In contrast, women continued to experience modest gains in real income after 1976, although female incomes still averaged only about two-thirds of male incomes in 1991.

Coinciding with these changes in income have been changes to social programmes. Over the past half-century, Canadian governments have introduced universal health care and have subsidised higher education. They have also introduced or altered social programmes that enhance the incomes of needy households (see Table 5). At the same time, the less needy were adversely affected by shrinking benefits, and increased taxes cut into the disposable income of the more affluent. Another important social policy initiative, the de-institutionalisation of the psychiatrically and physically disabled, put more low-income individuals into the private rental market.

How did the living arrangement of persons in private households and the amount of rental housing consumed change? The composition of private households-living arrangement-changed rapidly. In 1991, about 71 per cent of all private households contained one census family, with or without additional non-family persons. Because of the marriage bust, this was down from 80 per cent in 1971. The big increase nationally was in persons living alone: 23 per cent of all households in 1991, up from 13 per cent in 1971.

That household formation slowed in the first half of the 1980 s is related to declining affordability. Table 6 presents estimates of the number of 'potential' households that could form if every husband-wife couple, and all other persons aged 20 or older, were each to occupy a separate dwelling. The affordability index presented in Table 6 for Canada measures the cost of housing relative to the average income of a potential household; it shows that housing became more affordable over time, except between 1981 and 1986. As housing became less (more) affordable, household formation slowed 


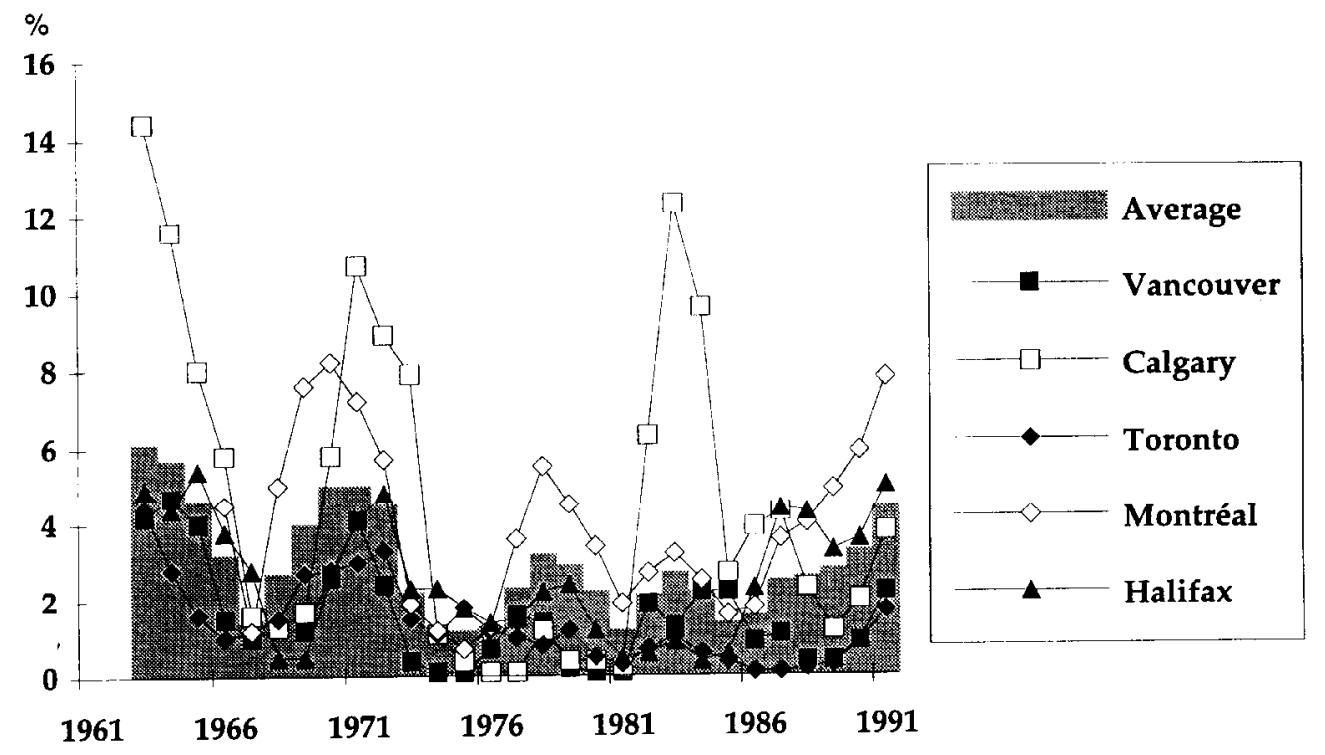

Figure 2. Vacancy rates for privately initiated apartment buildings containing six or more dwellings, selected Canadian metropolitan areas, 1963-91. Source: Canadian Housing Statistics, various years. Notes: 'Average' is weighted average of cities across Canada that are included in CMHC's Vacancy Survey. Vacancy rates shown are for the month of June in 1963 through 1972, December in 1973 and 1974 , and October in 1975 through 1991.

(gained). How did the consumers cope who might otherwise have formed separate dwellings? Coping strategies might include delay in home-leaving among young single adults, delay of marriage, and sharing a dwelling with a partner instead of living alone. However, although household formation slowed during the early 1980s, the amount of doubling up was not sufficient to cause average household size to rise.

Arguably, the demand for rental housing by a household, once formed, can be viewed in terms of household preferences (usually proxied by household size, presence of children and family composition), the price of renting, the selling price of owner-occupied housing, access to home-ownership, and consumer income. Rudel (1987) argues that family size-long thought to be an important determinant of the shift from renting to owning-became less important in the 1970 s relative to economic considerations. Figure 1 reveals the rapid increase in the price of renting that occurred in the 1970s and early 1980s. As real incomes began to drop in the late $1970 \mathrm{~s}$, the renter households that did form tended to consume less housing-a smaller, lower-quality, less accessible, or otherwise less adequate dwelling-or possibly a different tenure (e.g. home-ownership, cooperative housing) than would have been the case had housing not become less affordable. At the same time, the ranks of renters were swelled by non-traditional households (which typically have modest incomes). Again, this should have increased the demand for smaller or lower-quality rental dwellings. Evidence of this decrease in housing consumption (relative to home-owners) has already been noted in Table 2 .

Finally, the attractiveness of home-ownership is tied to the potential for capital gains. In most parts of Canada, there were three recent house price bubbles: $1974-75,1980-$ 81 and 1987-89. With each bubble, some households that might otherwise rent were drawn into home-ownership. In terms of access to home-ownership, the introduction of condominia to Canada was also important. Before the mid 1960s, the con- 


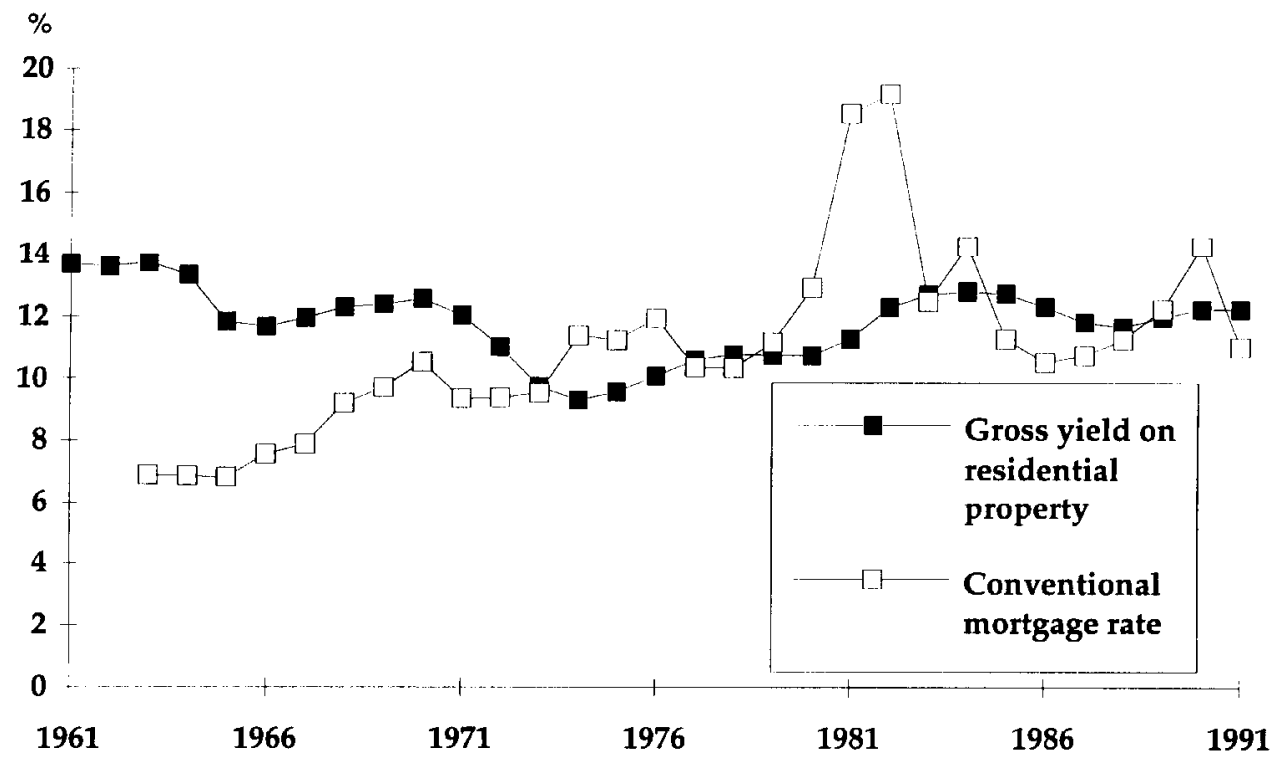

Figure 3. Gross yields on residential property, Canada, 1961-91. Source: Gross yield calculated as ratio of imputed plus gros s rents paid (see source to Table 2) to the asset value of the housing stock (see source to Table 3). This is a maximum gross yield because the value of the housing stock does not include the value of the land on which it is situated.

sumer who wanted to live in a high-rise or estate town-house generally had to rent. Equity cooperatives were one possibility for the consumer interested in home-ownership, but these were not widely used. The condominium form enhanced access to home-ownership, and many of the early condominium projects were marketed specifically as a lowcost alternative to renting. ${ }^{7}$

Who currently lives in rented dwellings in Canada? From the 1986 Census public use sample, we can construct estimates of the likelihood of living in a rented dwelling by gender and marital status for single years of age (see Figure 5).

- Married: Among both men and women, the incidence of renting declines sharply with age, bottoming out at about 20 per cent at around age 40 , and then increasing above age 60 .

- Single: Under the age of 15, singles live principally in a parent's home and thus have a corresponding incidence of renting. Over 15, home-leaving becomes more prevalent, and the transition is typically to rented accommodation. There is some home-ownership at older ages, but throughout the prime home-buying years (early adulthood through age 50), the majority of singles are renters.

- Divorced: Divorced men and women have about the same high incidence of renting as do singles of the same age.

-Widowed: Widowed men and women are more likely to be renters than are married persons of the same age. However, they are less likely to rent than are their divorced or single peers.

\section{Supply of Rental Housing Stock}

Let us simplify the market for new rental stock by imagining initially on the one hand a group of developers who construct and supply new conventional rental housing, and on the other hand a group of investors who purchase such buildings to profit from renting dwellings to tenants. In such a market, the price of an apartment building as an asset is determined by the expected flow of net 


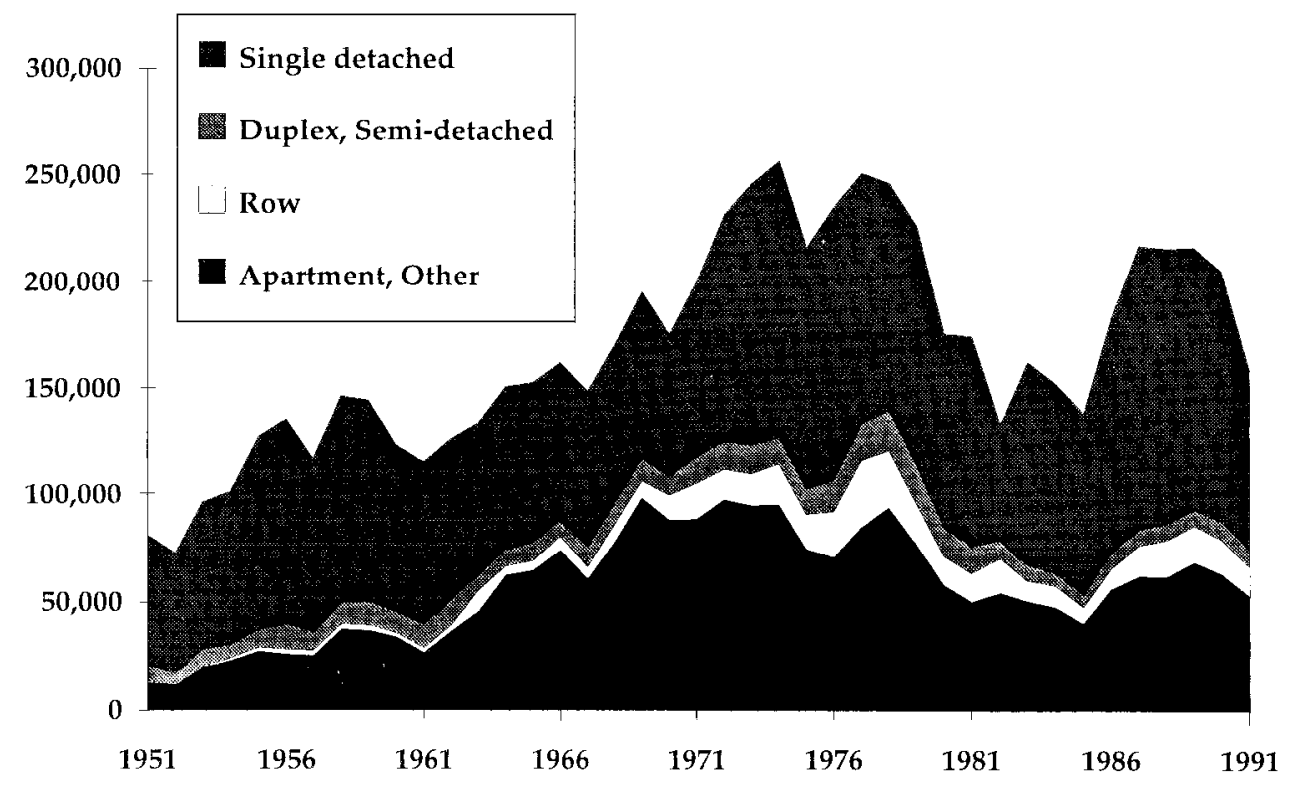

Figure 4. New dwelling completions, showing type of dwelling, Canada, 1951-91. Source: Canadian Housing Statistics, various years.

rental revenue. The profitability of supplying new buildings into this market is determined by rents, costs of construction (labour, building materials, financing and land costs), production technology and planning and building regulation.

Land costs are one important component of construction costs. The available price series for residential land in selected metropolitan areas across Canada is shown in Figure 6. While these series extend back only to 1976, they do show the bubbles in land prices that occurred in many cities at the same time as the price bubbles for owneroccupied housing.

The prices paid for building materials also changed over time. New materials were brought to market: e.g. plastics, new forms of sheathing and particle board. Inexpensive building component systems became commonplace, reducing the need for skilled construction labour. Also helpful in moderating costs were innovations in factory-assembled parts: e.g. roof trusses, pre-hung doors, prefabricated windows, kitchen cabinets. Overall, the prices of building materials fell slightly relative to consumer prices during the $1970 \mathrm{~s}$ and $1980 \mathrm{~s}$ (see Figure 7).

The relative cost of construction labour also changed over this period. Before 1976, unit labour costs had been increasing quickly relative to consumer prices generally. However, after 1976, unit labour costs increased only modestly, typically by less than the increase in CPI. Again, see Figure 7.

Changes in the cost of financing have also been important in determining the supply of rental housing stock (see Figure 8). Nominal interest rates in Canada increased steadily through the $1960 \mathrm{~s}$ and $1970 \mathrm{~s}$, peaking at almost 20 per cent in the early 1980 s. Since then, interest rates have remained high (relative to the 1960s) in both nominal and real terms.

Finally, there have been important changes in construction technology in recent decades. McKellar (1993, p. 149) mentions standardisation in design, prefabrication of components, the flying-form construction technique (a concrete forming system that streamlines on-site pours) and the European climbing crane. These changes made it 
Table 3. Selected investment and national balance sheet indicators, Canada, 1951-91 (\$bn)

\begin{tabular}{lrrrrr}
\hline & 1951 & 1961 & 1971 & 1981 & 1991 \\
\hline Investment & & & & & \\
Gross fixed capital formation & 4.6 & 8.8 & 21.6 & 86.1 & 132.4 \\
Residential & 1.1 & 2.2 & 5.6 & 20.6 & 41.5 \\
$\quad$ New construction & 0.7 & 1.4 & 4.1 & 11.2 & 18.9 \\
$\quad$ Alterations and improvements & 0.3 & 0.4 & 1.1 & 6.4 & 12.0 \\
$\quad$ Transfer costs & 0.1 & 0.3 & 0.5 & 3.1 & 10.5 \\
National balance sheet & & & & & \\
Total assets & - & 299 & 729 & 2861 & 5947 \\
Residential structures & - & 28 & 75 & 290 & 652 \\
$\quad$ Rented dwellings & - & 8 & 25 & 81 & 177 \\
Owned homes & - & 19 & 50 & 210 & 475 \\
\hline
\end{tabular}

Sources: Investment data from National Income and Expenditure Accounts: Annual Estimates. National balance sheet data from National Balance Sheet: breakdown of residential structures into owned and rented capital on the basis of imputed and gross rents paid in Table 2.

Note: - indicates data not available.

possible to construct high-rise buildings at lower unit costs and enabled the landlord downstream to profit from the economies of operation afforded by large structures.

Standardisation also improved the liquidity of the rental housing stock. An investor who purchases an apartment building with a unique design, materials or construction technique must be wary of the need for costly repairs downstream. The problems and costs of operating and maintaining standardised buildings are better known, and hence more predictable.

This discussion has focused on the supply of new stock. However, also important is the supply of rental housing stock that arises from the conversion of existing structurese.g. a detached dwelling converted into a duplex structure. Developers who convert structures to rental housing face many costs that are similar to new construction: for materials, labour and financing. What makes conversion activity different is partly that it is thought to be more labour-intensive than new construction and partly that profitability is sensitive to the resale price of structures to be converted.

\section{Supply of Rental Accommodation}

Involved in the market for rented accommodation are firms in the business of property ownership, property management and building repair and maintenance, as well as manufacturers and suppliers of maintenance equipment and supplies. We have relatively little information about these firms. Instead, in this section, we develop a theoretical framework for viewing rental investment, then review post-war changes that have affected the supply of accommodation.

\section{The Landlord's Problem}

Suppose an individual investor is thinking of purchasing an apartment building for the purpose of renting out individual flats. Let us assume that the attractiveness of such an investment is related solely to the present value of the after-tax profit to be gained from the stream of gross rents generated and the resale value of the building downstream. The investor as landlord intends to enter into a (lease) contract with each prospective tenant which specifies a rent to be paid to the landlord, the rights and responsibilities of the tenant, the obligations of the landlord to 
Table 4. Population and families, Canada, 1961-91

\begin{tabular}{lrrrr}
\hline & 1961 & 1971 & 1981 & 1991 \\
\hline $\begin{array}{l}\text { Population (thousands) } \\
\text { Total population (usual residents) }\end{array}$ & 18238 & 21568 & 24203 & 27179 \\
$\begin{array}{l}\text { Persons in collective dwellings } \\
\text { Persons in private dwellings }\end{array}$ & 484 & 393 & 406 & 447 \\
$\quad$ Non-family persons & 1659 & 2323 & 3195 & 4173 \\
$\quad \begin{array}{l}\text { Persons in families } \\
\text { Living with spouse }\end{array}$ & 7600 & 9184 & 11222 & 12803 \\
$\quad$ Lone parent & 347 & 479 & 714 & 955 \\
$\quad$ Child & 8148 & 9189 & 8667 & 8801 \\
Families (thousands) & & & & \\
Families in private dwellings & 4147 & 5071 & 6325 & 7356 \\
$\quad$ Husband-wife families & 3800 & 4604 & 5612 & 6401 \\
Female lone parent & 273 & 371 & 589 & 786 \\
$\quad$ Male lone parent & 75 & 99 & 124 & 168 \\
\hline
\end{tabular}

Notes: Columns may not sum due to rounding; 1961 and 1971 family counts include families living in collective buildings; n.a. indicates data not available.

Sources: Computed from published reports of the quinque nnial censuses of Canada since 1961, and the 1981 Census public use sample (family) file.

maintain and operate the building, and legal remedies.

Suppose that we simplify the problem confronting our investor initially by assuming zero transactions costs, perfect information and no risks either in renting specifically or in investing generally. In a riskless world, the investor would foresee the present value of the after-tax profits associated with this enterprise. If our investor is identical to other demanders and suppliers in the market for housing stock, the market price for an apartment building would rise or fall until the present value of the after-tax profits provides the same rate of return is identical to that for other financial assets.

In reality, the investor's problem is more complicated than this, even if we continue to absent risk and imperfect information. Indicative here are decisions made by the investor about renovation: see Arnault (1975). Normally, a building (here taken to include plant, fittings and equipment) deteriorates over time. Some of this deterioration is offset by ongoing maintenance, and lease provisions may require that the landlord keep the dwellings in a specified state of repair. However, the landlord usually has some discre- tion-e.g. repainting can be delayed, a broken pump can be replaced with a new pump with a lower capacity, small landlords can choose to do repair work themselvesand can choose from among diverse streams of future renovation expenditures. With each stream of expenditures is associated a sequence of lease arrangements (including rent), a downstream resale value for the building, and hence potentially a distinct present value of after-tax profits.

A related complication for the investor is selection of tenants. Some tenants are more costly to serve. While the landlord may be able to evict such tenants eventually, a costly tenant can reduce the profitability of the investment. However, this does not imply that costly tenants will not be served in a competitive market. Rather, market rents will be higher for costly tenants, and investors may well target particular kinds of tenants to attract to their buildings. See Guasch and Marshall (1987) and Miron (1990).

The economic roles of the landlord are broadly twofold: financier and property manager. As financier, the investor chooses when to purchase the building and how much to pay for it, how to finance the purchase, how 


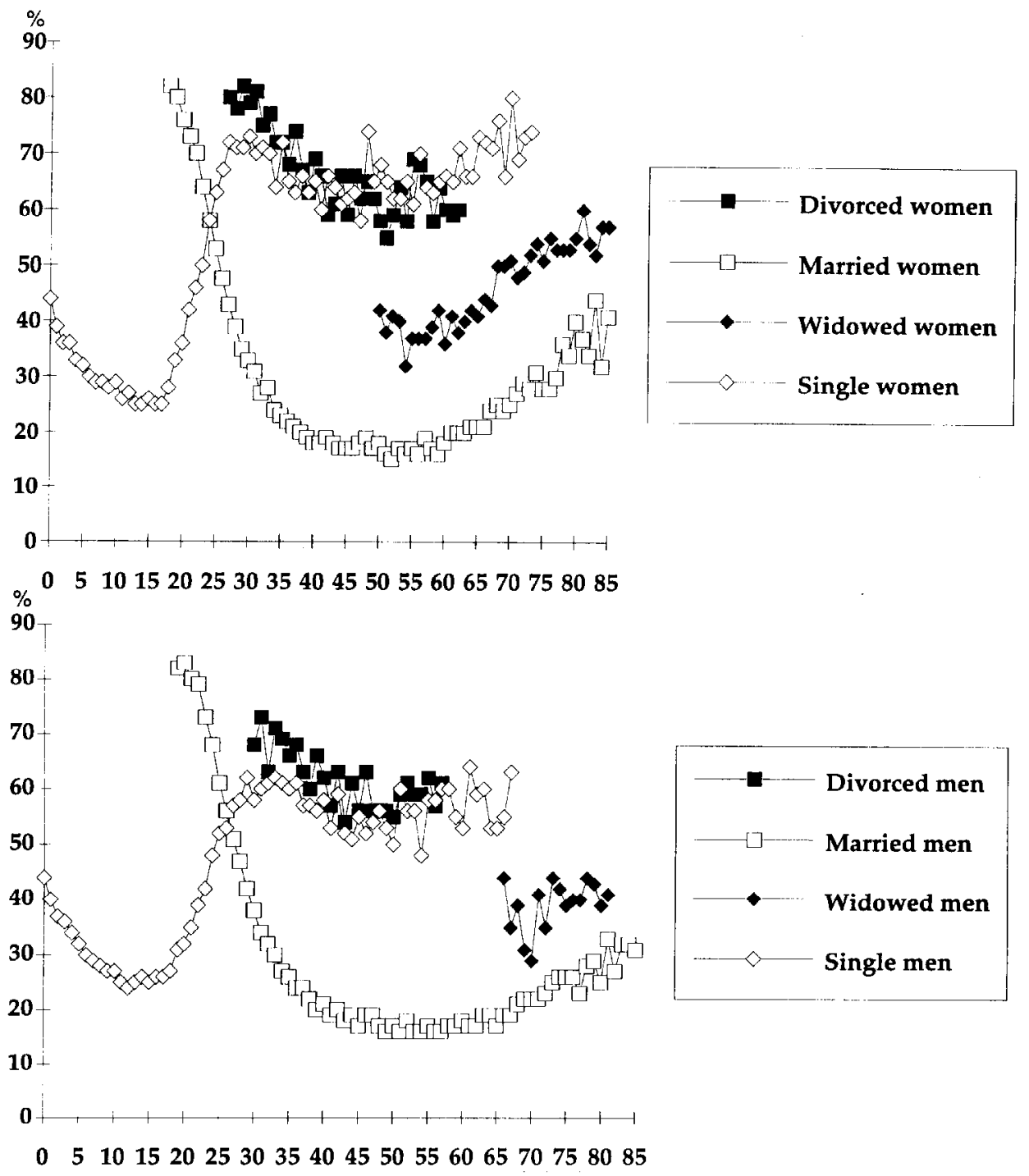

Figure 5. Percentage of women (above) and men (below) living in rented dwelling s by marital status at single years of age, Canada, 1986. Source: Computed by author using the 1986 Census Public Use Sample (Individual File). Notes: Percentage not displayed where cohort sample size is under 100 persons. Data shown for age 85 include all persons aged 85 or older.

well to maintain the building, what parts of the rental housing market to target, and when to dispose of the building (sell it or convert it to another use). As property manager, the landlord seeks to operate the building efficiently on a day-to-day basis. This involves finding both the least-costly way of providing a given level of service and the least-costly tenants from within the market segment to which the building is targeted.
Where the landlord is a small owner (for example, rents an upstairs flat in his or her own home), the owner may well combine both roles. In a larger apartment building, the owner may well devolve property management to an on-site agent. ${ }^{8}$

Investment in rental housing is not without a risk that arises essentially because the investor typically borrows long-term (through a mortgage) to lend short-term (through 
苞

$\stackrel{\infty}{\Xi}$

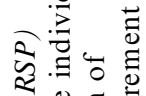

品

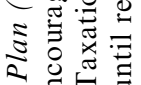

的获

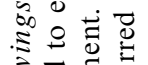

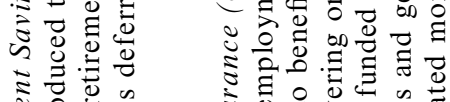

Ð

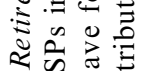

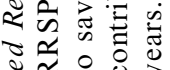

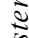

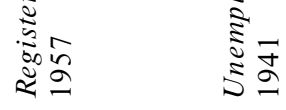

(1)

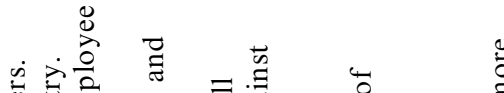

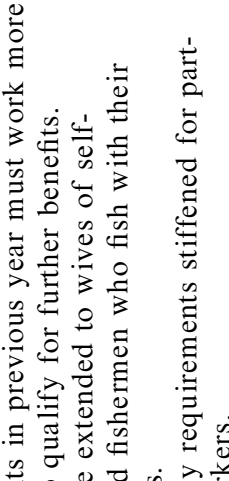

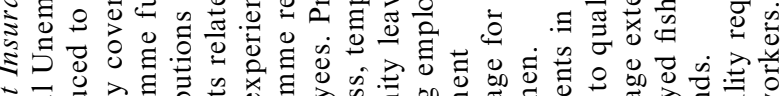

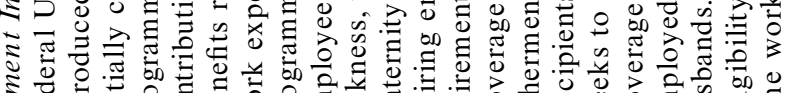

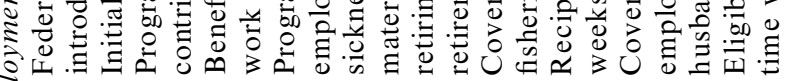

ลิํㅗㅇ

$\stackrel{n}{\stackrel{2}{2}} \stackrel{\infty}{2} \stackrel{\infty}{2}$

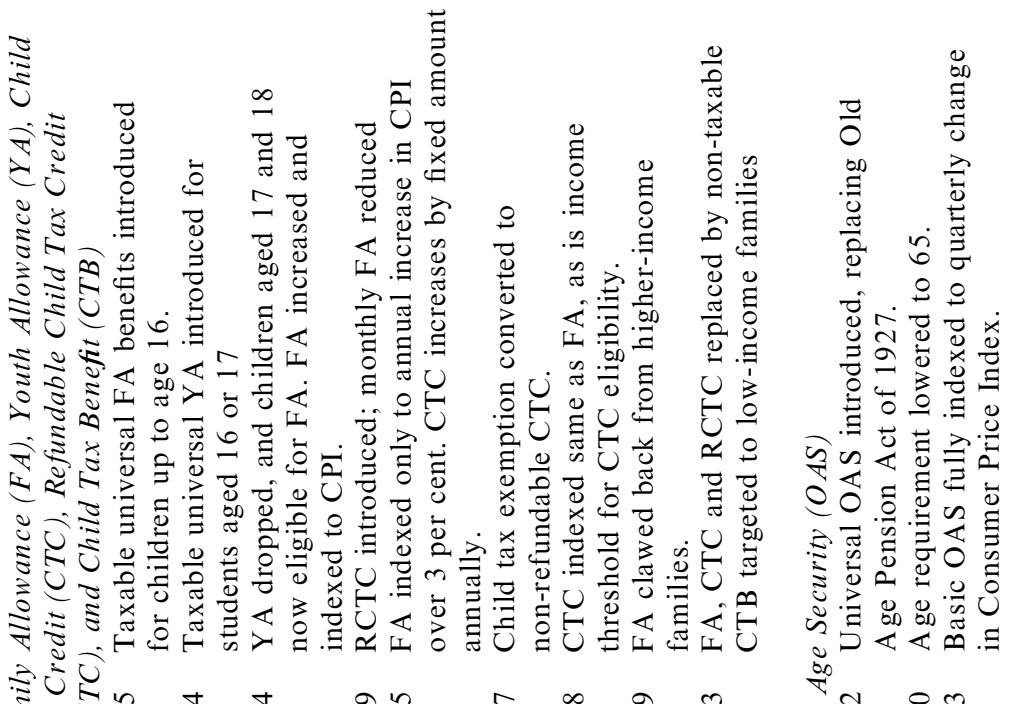

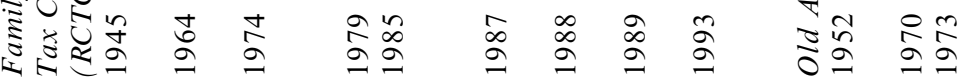




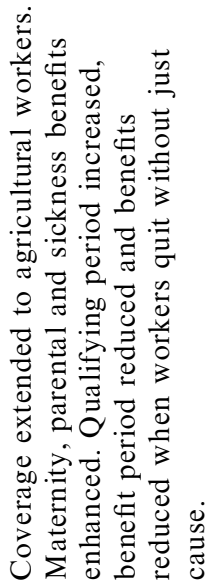

๙

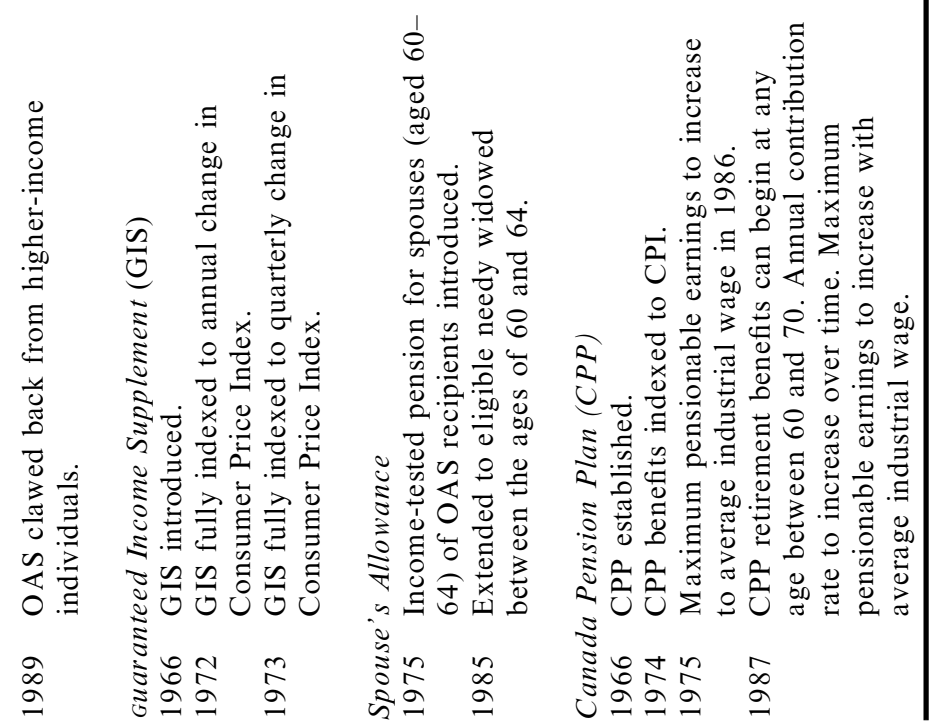


Table 6. Potential households by category, Canada, 1971-91

\begin{tabular}{lrrrrr}
\hline & 1971 & 1976 & 1981 & 1986 & 1991 \\
\hline Persons, aged 20 or older, & & & & & \\
not living with spouse & & & & & 3838 \\
$\quad$ Never married & 2272 & 2550 & 3034 & 3557 & 699 \\
$\quad$ Separated/spouse absent & 567 & 637 & 727 & 789 & 1190 \\
$\quad$ Widowed & 941 & 1042 & 1157 & 1249 & 886 \\
$\quad$ Divorced & 174 & 302 & 500 & 690 & 6401 \\
Husband-wife families & 4605 & 5169 & 5611 & 5881 & 13014 \\
Potential households (total of above) & 8559 & 9699 & 11029 & 12166 & 1018 \\
Private households & 6035 & 7166 & 8282 & 8992 & 10018.77 \\
Formation rate & 0.70 & 0.74 & 0.75 & 0.74 & 0.77 \\
Affordability index & 100.0 & 80.0 & 75.0 & 77.3 & 70.7 \\
\hline
\end{tabular}

Sources: Published reports of the Census of Canada (various years), potential households, formation rate and affordability index calculated by author.

Notes: Since 1981, Census includes common-law couples in counts of husband-wife families. Formation rate is the ratio of private households to potential households. Affordability index is ratio of housing component of CPI divided by personal disposable income per potential household: adjusted to equal 100 in 1971 .

tenancy leases that typically are only 1-3 years in length). The investor generally borrows by taking out a mortgage amortised over 20-35 years. Presumably, a knowledgeable landlord can accurately predict the profitability of rents obtained on the initial lease. However, because the rental market may change unexpectedly in the future, the landlord runs the risk that rents downstream are less than was expected at the time the building was financed.

In one sense, the problem is the same for any rental enterprise: for instance, a car rental firm. What makes car rentals different from apartment rentals, however, is the stock market in which rental equipment is resold. In the case of car rentals, that would be the second-hand car market. Where car rental firms are a small component of the used car market, a car rental enterprise will find that resale price is insensitive to outcomes in the car rental market. Put differently, the car rental agency can dispose of unneeded cars in the largely-unrelated market for second-hand, owner-driven vehicles.

The closest equivalent to a car rental enterprise would be a landlord who owns and rents out a single dwelling (freehold or condominium); the landlord there has the option of selling the dwelling within the market for owner-occupied dwellings, and the cost of physically converting the dwelling to enable owner-occupancy are zero or negligible. In contrast, the landlord who owns a larger apartment building may well find that conversion to another use (for example, an office building) is unprofitable and that selling individual dwellings to home-owners would require conversion to a condominium, cooperative, or co-ownership project. Otherwise, demanders in the market for stock would consist only of those who intend to continue that rental housing enterprise, and the resale price of the building will rise or fall with changes in downstream rents.

What complicates this argument is the variety of property ownership. Freehold ownership, in which the owner has title to land and building, has been the traditional form of home-ownership in Canada. Started in Canada in the 1960s, condominium ownership gives an owner title to a dwelling within a project and an obligation to pay a fixed share of the costs of maintaining the common elements (typically, land and superstructure) of the project. Where the landlord holds title to the individual rental dwelling in freehold or condominium ownership, reselling that 


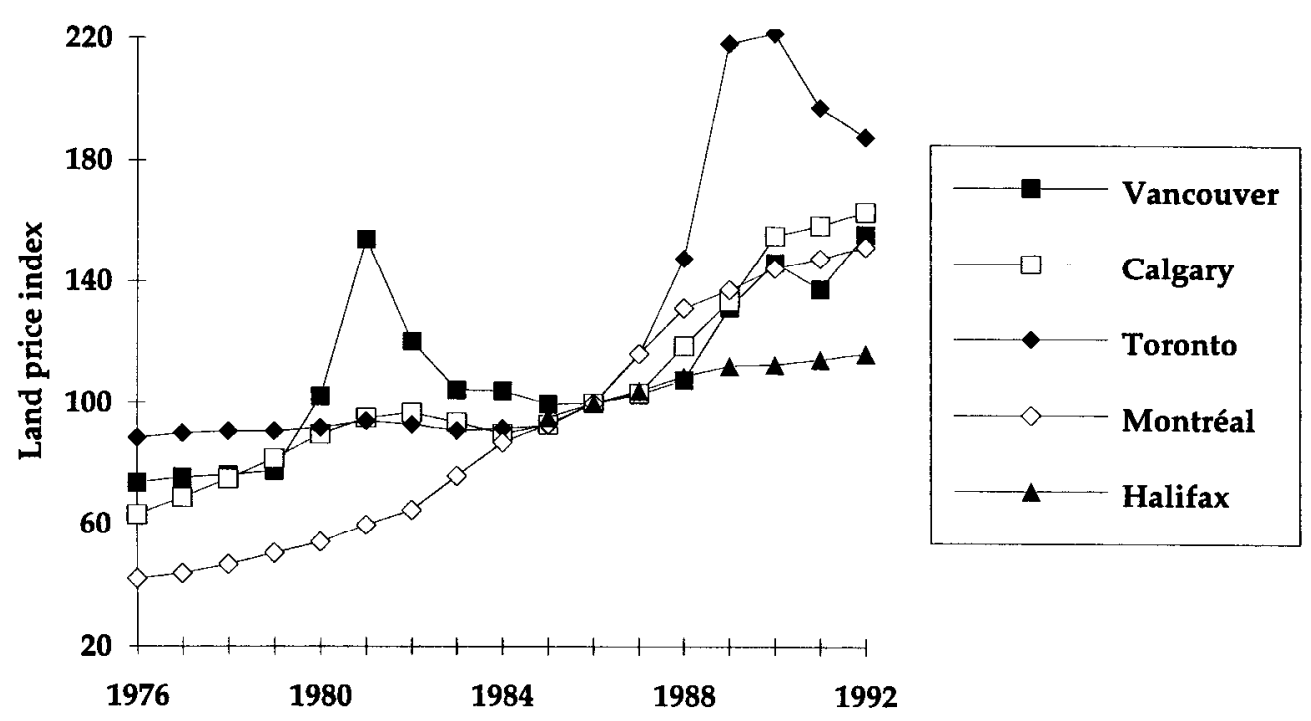

Figure 6. Land component of New House Price Index $(1986=100)$, selected Canadian metropolitan areas, 1976-92. Sources: Calculated from Statistics Canada (various years), New House Price Index. Series are linked at 1981 and 1986.

property within the market for owner-occupied housing is relatively easy.

As a thought experiment, let us ignore the effects of income taxation, inflation and discount rate variation, and imagine that the investor finances the purchase of the apartment building with a 30-year level-payment mortgage, and then negotiates 30-year netnet leases with tenants. Under these net-net leases, tenants pay a fixed monthly rent (to cover mortgage interest expense plus the opportunity cost of the investor's equity) for the next 30 years, plus a varying monthly amount representing the tenant's share of expenses for heat, light, utilities, property taxes, insurance, ground skeeping, building maintenance and depreciation, superintendency, and all other costs incurred by the landlord. In other words, the lease would foresee every contingency and the tenant would bear all risks in regard to changes in the cost of maintaining the building during the 30-year period. In this situation, the investor's behaviour is determined entirely by speculation about the (net-net) monthly rent upon renewal 30 years downstream, or equivalently the resale price of the building.
If these are anticipated to rise, the investor would earn above-normal profits: if the rent or resale price declines, the investor would not earn even normal profits. In this case, the investor's role is simply that of an arbitrageur between two markets: buying rental housing stock when the current stock price is relatively low, and selling stock when the current stock price is too high in light of rents in the market for accommodation.

In Canada, such long-term residential tenancy agreements are uncommon. The closest equivalent is the 'time share' tenancy sometimes used to sell recreation property. Instead, landlords typically assume superintendency, maintenance and depreciation expenses, and property taxes; sometimes, they also include heat, light and/or utilities with the dwelling. In so doing, landlords gamble that market rents will increase downstream as quickly as these expenses. Long-term agreements may be uncommon because it is difficult to envisage a lease that would adequately cover contingencies.

Uncertainty about prospective tenants adds another complication. There are two ele- 


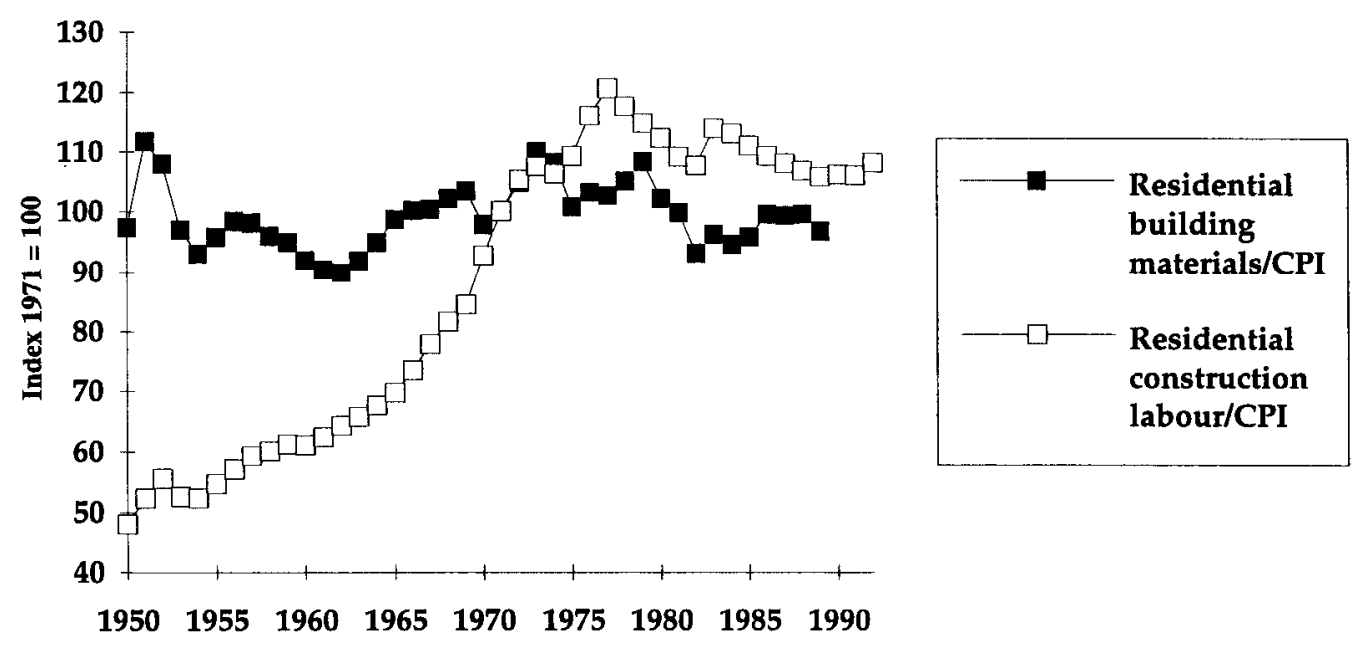

Figure 7. Residential construction material and labour input prices, Canada, 1950-92. Source: Computed by author from Construction Price Statistics (cat. 62-007), various years. Notes: Residential construction building materials index links 9 categories of principa 1 components, material cost index for single-family house s only, and 4 categories of materials. Index not published after 1989. Residential construction labour index links weekly wages in manufacturing, labour cost index for single detached houses only, and union wage rate index for major cities of 16 construction trades.

ments here. One is the uncertainty that arises because rental dwellings are not all identical. Because of heterogeneity in the stock, the landlord knows that tenants and other landlords are unlikely to have perfect knowledge of market rents. If they did, the rent everywhere for an equivalent dwelling would be the same, and landlords would each find that the demand for their dwellings is perfectly elastic at this rent. In the absence of perfect information, the higher the asking rent, the longer the landlord will have to wait before finding a willing tenant: see Stull (1978) and Miron (1990). The second element is the uncertainty that arises because tenants are not all identical. The landlord faces the prospect of adverse selection (wherein prospective costly tenants misrepresent themselves as low-cost tenants) and moral hazard (wherein tenants fail to care for the dwelling as might a home-owner). See Miceli (1989).

\section{Post-war Changes in the Supply of Rental Accommodation}

Fallis (1993, p. 79) argues that the technology for producing rental accommodation in
Canada has not changed substantially since 1945. However, the business of renting accommodation may well have changed in some important ways. One example is the retrofit of existing buildings with computerised systems to control more efficiently heating and air conditioning equipment. Another important change is the development of new cost-saving equipment (e.g. energy-efficient lighting systems) and materials (e.g. wear-resistant carpets). Other innovations reduced the labour needed for maintenance (e.g. lowmaintenance wall coverings and surveillance cameras). Still another innovation has been the upgrading of management information systems.

Important too have been post-war changes in sources and methods of financing: see Poapst (1993). Revisions to the federal Bank Act in the late $1960 \mathrm{~s}$ authorised chartered banks to enter the mortgage lending business and removed the 6 per cent interest rate ceiling. Canada's principal banks are large financial institutions; each with many hundreds of branches across the country. They intermediate in the mortgage market; retailing mortgages to landlords, developers and 


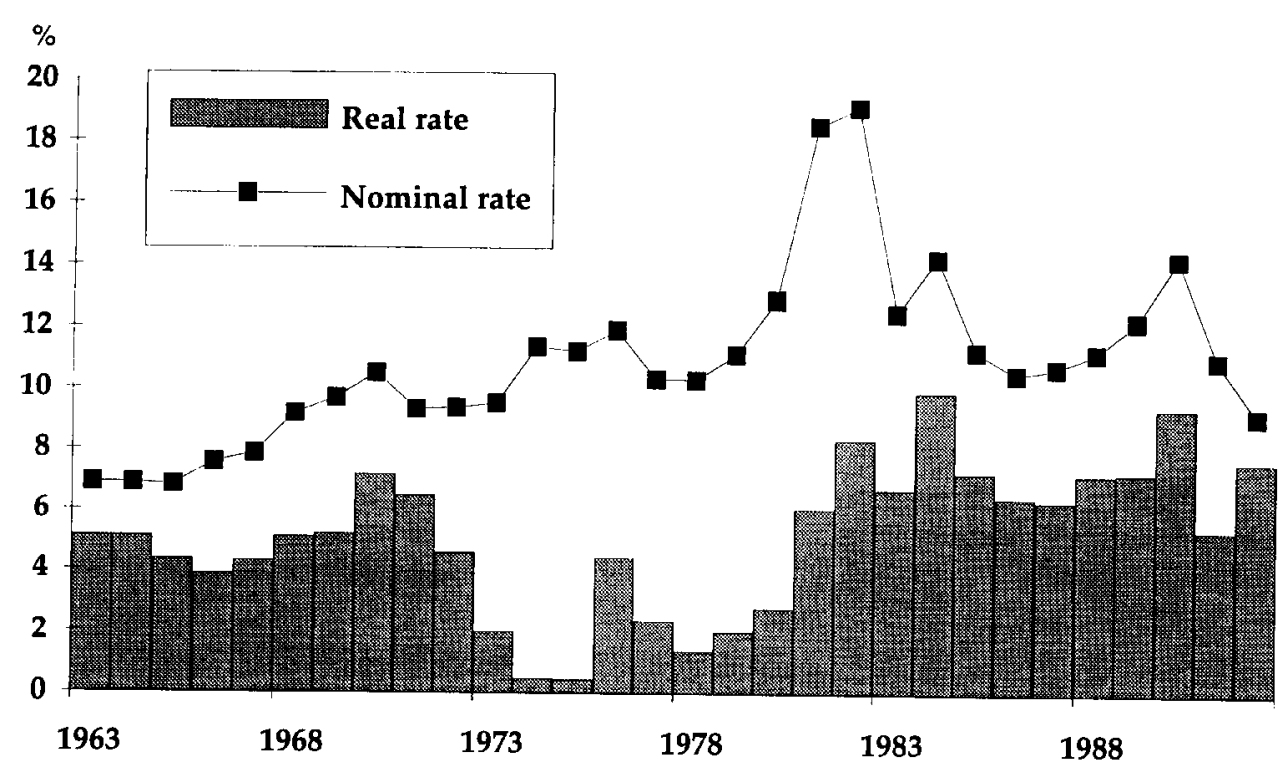

Figure 8. Average interest rates on new residential mortgage approvals, Canada, 1950-92. Sources: Nominal rates from Canadian Housing Statistics (various years); rate for three-ye ar term in June of year. Real rate is nominal rate less year-over-yearincrease in CPI.

home-owners on the one hand, and then pooling or repackaging them for investors on the other hand. As a result, the market for housing finance is more liquid and competitive. Consumers, developers and landlords benefit from more flexibility and variety in mortgage terms and better service.

The extension of NHA mortgage insurance to rental buildings and legislation authorising private mortgage insurance were also important. So too was the introduction by Canada Mortgage and Housing Corporation and lending institutions of mortgage-backed securities (collatoralised mortgage obligations) to increase the supply of mortgage funds.

Also important have been other innovations in financing by which investors spread the risks involved in rental housing. The three traditional methods of investmentsole ownership, partnership and private corporation-were complemented by innovations such as limited partnerships and condominium syndication. As well, where investment becomes of sufficiently large scale, perhaps drawn by the attractiveness of spreading risk across cities, incorporation as a public company can be an attractive possibility. In the $1960 \mathrm{~s}$ and $1970 \mathrm{~s}$, some major corporate integrated developer-landlords did emerge in Canada, only to run into financial difficulty downstream. The condominium sector has become important in the financing and supply of new rental units. As of 1991, up to one-half of all condominium apartments in Canada were occupied by renters. Although originally introduced to allow owner-occupancy in multi-unit buildings, condominiums can provide small landlords with a liquid investment, well-defined monthly costs and the ability to realise capital gains by reselling the dwelling to an owner-occupier (or another landlord) at some future date. This has been occurring both conventionally (for example, when condominium ownership is used to syndicate a rental building) and non-conventionally (when the condominium building is home to renters and owners).

\section{Post-war Changes in Taxation}

Over the past half-century, changes in in- 
come taxation have affected the profitability of investment in rental housing construction. ${ }^{9}$ Many of these changes have been driven, not by housing policy, but to prevent abuse by taxpayers claiming business losses on 'rental properties' acquired by the taxpayer for other purposes.

Small investors are the group most affected by changes in income tax provisions: see Miron (1988, pp. 255-257) and Clayton Research Associates Limited (1991, pp. 44-49). New buildings typically generate rents that are low relative to construction costs for the first few years; however, with inflation, rents increase over the years making the investment more attractive. This feature of rental housing makes it attractive to small investors such as doctors, lawyers, accountants and other professionals who are currently in a high marginal tax bracket and hence are willing to incur losses now in return for a good return downstream (for example, upon retirement). A key factor for such investors is allowable depreciation. In 1954, new Capital Cost Allowance (CCA) provisions defined allowable depreciation expense for the purposes of income taxation. CCA for woodframe buildings, for example, was initially set at a liberal 10 per cent annually (compared with 5 per cent for concrete and steel reinforced buildings), reduced to 5 per cent in 1978, and 4 per cent in 1987; the CCA became 4 per cent for all rental buildings in 1987. CCA provides an incidental subsidy to landlords to the extent it exceeds economic depreciation. However, when a building is eventually resold, the excess of market value over depreciated value (up to original cost) is recaptured into income for that year for tax purposes; any excess over original cost would be capital gains. In effect, liberal CCA rates allow landlords to defer some income tax until disposition.

In another major revision to the federal Income Tax Act in 1971, investment in rental housing was made less attractive for small investors. Losses created by capital cost allowances for rental property were no longer deductible from non-rental income, except for life insurance companies and corpora- tions in the business of real estate. Also, the pooling of recapture on the sale of one building with CCA losses on other buildings was ended. As well, 50 per cent of capital gains became taxable on most assets; a notable exception being a taxpayer's principal residence. ${ }^{10}$ That the Great Apartment Boom ended shortly thereafter suggests that the effect of these changes on investment in rental housing was substantial.

The federal government introduced the Multiple Unit Residential Building (MURB) programme in 1974 to make rental housing more attractive to small investors. Amendments to the Income Tax Act enabled those investing in MURBs to deduct from personal income rental losses incurred through capital cost allowances and soft costs. The MURB programme led to a splurge of new housing investment; approximately 195000 units were approved under the MURB programme: the programme ended in 1979 , but was reactivated from 1980 to 1982 .

Other changes in the Income Tax Act have also affected the attractiveness of investing in rental housing. In 1974, the federal government revised the Income Tax Act to remove the tax deductibility of carrying charges on land awaiting redevelopment. Tax rules capping losses for limited partnerships that are commonly used in rental project syndication were introduced in 1986.

Another change that deterred would-be developers occurred in 1981 when the Income Tax Act was revised to treat soft costs as capital costs in rental buildings. Soft costs are expenditures by an investor that are indirectly related to the cost of acquisition: they include: mortgage application, insurance and guarantee fees; legal, accounting and appraisal fees related to acquisition; promotion, marketing and advertising costs; landscaping costs; other pre-opening and start-up costs; interest costs and property taxes during construction; architects' fees; cost of building permits. Prior to 1981, all soft costs could be deducted as expenses in the year paid. As of 1981, only selected soft costs could be expensed. For anyone other than life insurance firms and corporations in 


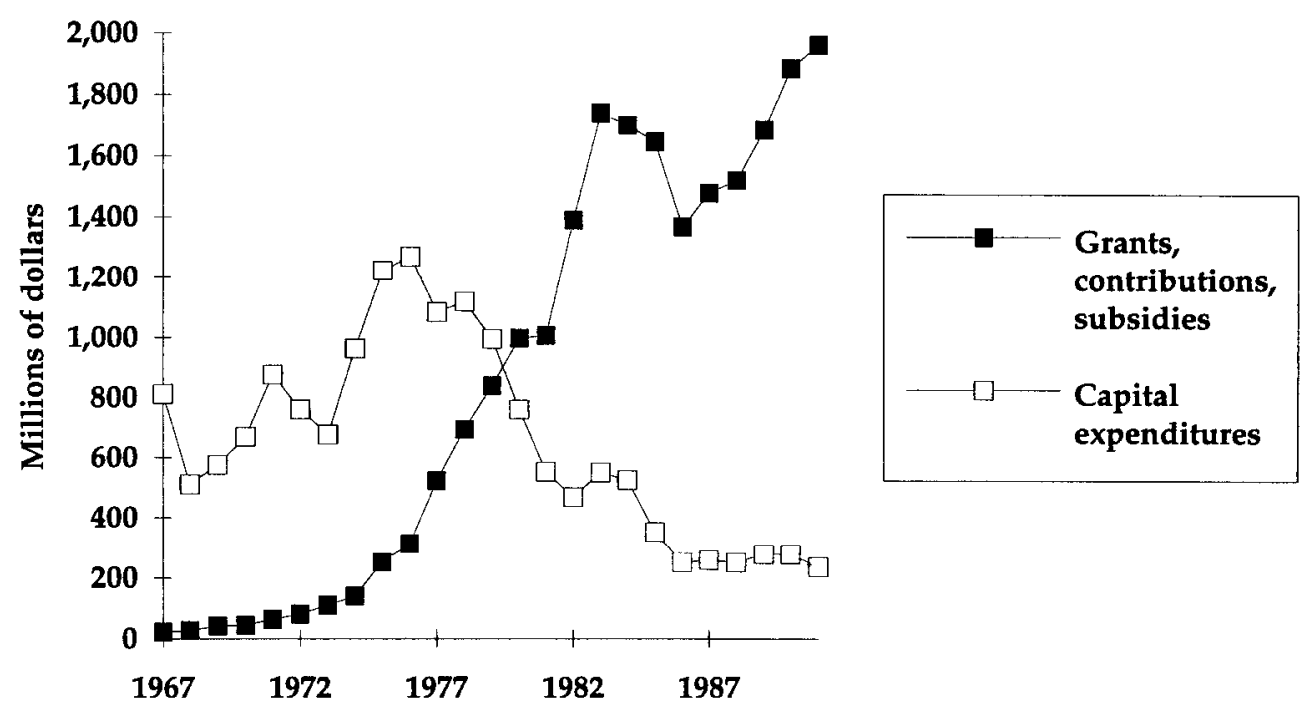

Figure 9. Grants, contributions and subsidie s (net budgeta ry expenditures: cash flow) and capital budget commitments (net non-bud getary funds: loans and investments) authoris ed under NHA (million s of current dollars), Canada 1967-91. Source: Canadian Housing Statistics (various years). Notes: Capital expenditures are gross new commitments during year. These data do not include loan repayments during year.

the real estate business, the remaining soft costs must now be capitalised into the value of the building and expensed as CCA downstream.

\section{A Half-century of Rental Housing Policy}

Over the past 50 years, governments at all levels in Canada have introduced policies that directly affect the operation of the rental housing market: see also Miron, 1988, pp. 238-267, Smith, 1981; Rose, 1980; and Firestone, 1951. Many of the early large-scale initiatives in housing policy originated at the federal level, and the federal government continues to be a major player. The amount of direct subsidy paid annually by the federal government under the NHA (which includes both rental and home-ownership housing) has climbed markedly over the past few decades (see Figure 9). By 1991, the federal government alone was spending $\$ 1.9 \mathrm{bn}$ annually on housing subsidies. These subsidies do not include capital grants paid under the NHA (shown separately in Figure 9), tax expenditures, loan guarantees and subsidies given by the provinces and territories either as part of NHA joint programmes or for a province's own housing programme.

Federal governments have had three principal objectives in spending this money. One has been to ensure that Canadians have access to decent housing at a price they can afford. The second objective has been to use the residential construction sector to spur a lacklustre economy, or to slow inflationary growth. The third objective has been to improve access to home ownership among Canadians of modest income.

The tools available to governments include direct expenditure, tax expenditure, regulation, research and development, and loan guarantees. To get a sense of the range of policies that have been tried, let us briefly review federal initiatives over the past halfcentury, focusing on direct expenditure and regulation.

Direct Expenditure: Urban Renewal and Social Housing

Under the Urban Renewal Program (URP), 
initiated in 1944, the federal government provided grants to cover 50 per cent of the costs incurred by municipalities in slum clearance. However, in 1968, the federal government imposed a moratorium on new URP approvals and on the development of large public housing projects. Whatever its merits, slum clearance had fallen into disrepute: eviction and expropriation were often necessary, and there were no assurances that dislocated individuals would be rehoused within their neighbourhood either during reconstruction or afterwards. Important too was that slum clearance disrupted local housing markets by creating a public housing agency that competed with private suppliers and adding to the risks confronting landlords.

URP was eventually replaced by four new less-obtrusive programmes. The Neighbourhood Improvement Program (NIP) provided grants to upgrade public infrastructure in designated low-income residential areas (see Figure 10). During the 5-year life of the programme, 479 neighbourhoods across Canada participated in it with costs (about $\$ 500 \mathrm{~m}$ ) shared by all levels of government. The Residential Rehabilitation Assistance Program (RRAP) gave subsidised loans to home-owners and landlords to upgrade substandard dwellings. Of the approximately 314000 units rehabilitated under RRAP between 1973 and 1984, 29 per cent were renter-occupied. The Rural and Native Housing (RNH) programme gave loans to individuals to finance home construction and renovation, as well as provide operating subsidies. The latter cover the difference between amortisation costs plus property taxes (plus heating costs as of 1986), and 25 per cent of income and are shared on a 75-25 per cent basis between the federal and participating provincial governments. Finally, the Community Services Contribution Program (CSCP) subsidised municipal capital projects: $\$ 400 \mathrm{~m}$ was distributed, with payments extended until 1984.

The first post-war initiative in public housing was the Federal/Provincial Public Housing Program introduced in 1949. This shared capital costs and operating losses of ap- proved projects on a 75-25 per cent basis between the federal and respective provincial governments. However, in spite of the generous federal subsidy, the provinces had undertaken to construct only $12000 \mathrm{dwe}$ llings by 1964.

Amendments to the NHA, introduced in 1964, included a public housing construction programme and a non-profit housing programme for the elderly that gave evengreater subsidies, and did become widely used. These amendments entitled provinces, municipalities and other public agencies to receive 90 per cent loans for the construction of low-income housing projects where tenants pay rents scaled to their income. The federal government covers half of the operating losses of these projects. These provisions were used to create more than 200000 public housing units. These provisions were effectively ended in 1978 .

Social housing programmes of the day were criticised because they led to the concentration of target groups in large, homogeneous, often high-rise, residential complexes with attendant social problems. One solution is to move target households into the private rental stock using shelter allowances or rent supplements. The federal government introduced a Rent Supplement Program in 1969. In 1977, British Columbia became the first province to introduce shelter allowances (for elderly renters only). Another solution is to integrate social housing into socially-mixed neighbourhoods. The provision of social housing in Canada took a first step in this direction in 1973 in the form of non-profit and cooperative housing programmes under NHA 15.1 and 34.18 (see Figure 10). Eligible organisations were entitled to receive 90 per cent loans with an interest rate subsidy of 8 per cent and a 10 per cent capital contribution. These deep-subsidy programmes were among the first wherein a federal low-income housing programme did not require matching financial commitments on the part of other governments. New Nonprofit and Cooperative Housing Programs were introduced in 1978 under NHA 56.1. Under these programmes, cooperative and 

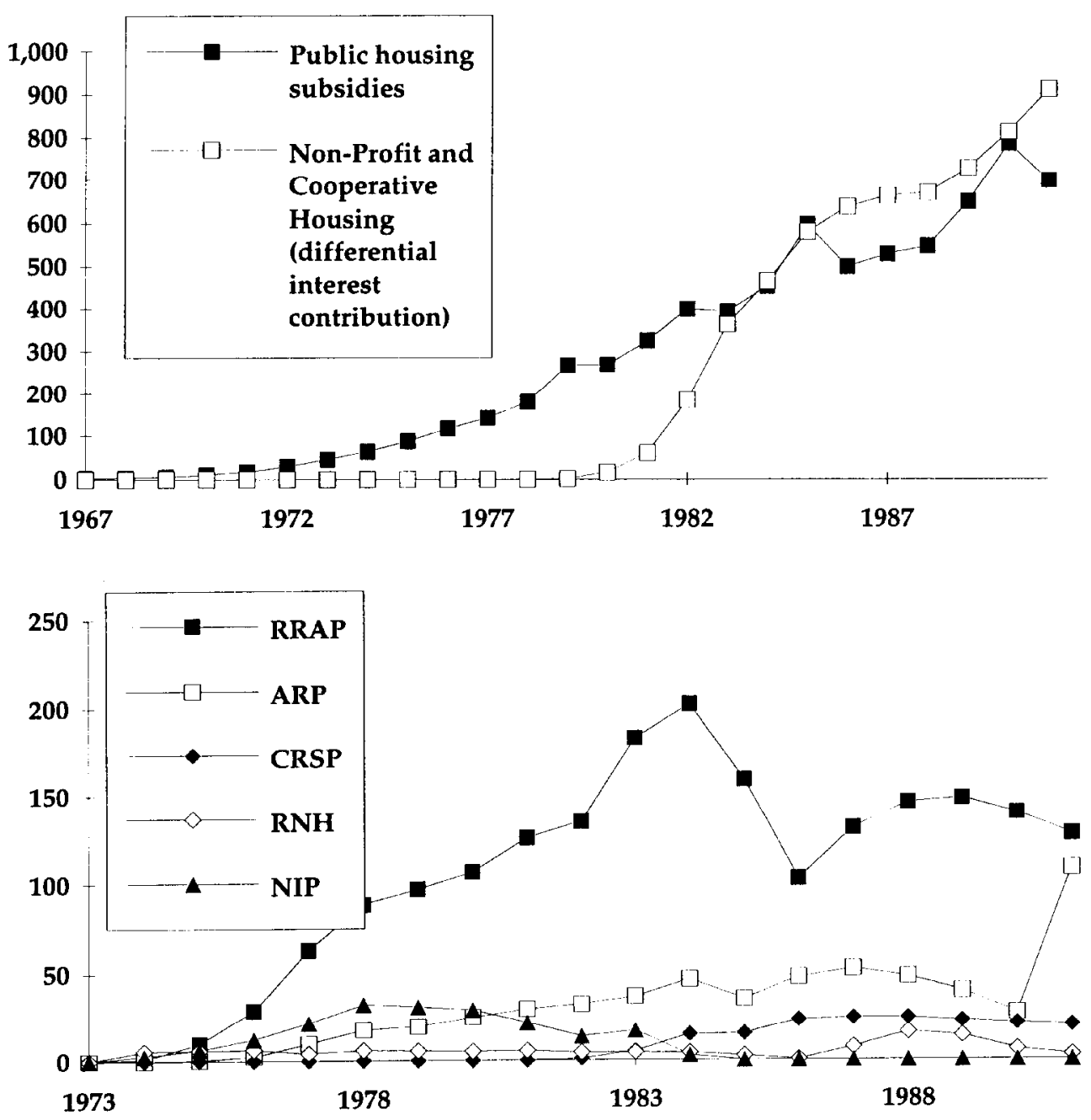

Figure 10. Grants, contributions and subsidies (net budgetary expenditures: cash flow) under selected NHA programmes (\$m), Canada, 1967-91. Source: Canadian Housing Statistics (various years).

non-profit housing agencies were entitled to receive maximum assistance equivalent to the difference between mortgage payments at market interest rates and at 2 per cent. Between 1974 and 1984, almost 124000 units were constructed with these substantial subsidies. Funding was also available to assist in the initial development stages of these projects.

In 1986, facing a severe budget deficit, the federal government ended these Non-profit and Housing Cooperative Programs. A new version of these programmes was introduced which targeted subsidies. Cooperatives could still construct projects for a socially-mixed clientèle, but an NHA subsidy was given only for low-rent units. By 1992, however, even this version was ended.

The federal subsidies for urban renewal and public housing are based on a common perspective; namely, that inadequate housing is a problem, rather than a symptom. They did not, for example, see blight and sub-standard housing simply as a symptom of poverty. Further, these programmes largely ignored how the housing market responds; how developers alter decisions about new construction and conversions; how landlords 
change their asset holdings and renovation decisions; how consumers respond in terms of living arrangement, tenure and housing consumption.

\section{Direct Expenditure: Supply of Private Rental Housing}

The federal government also sought to encourage the private sector to supply more low-rent housing. An early instance was the Limited Dividend (LD) programme, introduced in 1944. Loans were made to companies and individuals for the construction of new housing or to purchase existing housing. These loans limited investment return to 5 per cent and controlled rents. During 194664, 330 loans were approved, providing 28037 dwellings. In the mid 1960s, loan conditions were enhanced: loans were made up to 95 per cent of value; the investment return limit was increased; mandatory controls on rent were restricted to the first 15year period) and project eligibility was broadened to include hostels and dormitories as well as self-contained units. The LD programme has been inactive since the mid 1970s.

The LD programme illustrates the use of a policy approach in which developers are assured a fair rate of return on their investment. Another early instance of this approach was the federal Rental Insurance Plan, introduced in 1948, that provided long-term, low-interest loans to builders of low-rent housing and guaranteed landlords a 2 per cent net return on their investment. About 19000 units were constructed under this programme which ended in 1950 .

In 1975, the federal government introduced the Assisted Rental Program (ARP) to assist in the production of new affordable rental housing in the private sector. Interestfree loans of up to 10 per cent of the original loan amount in subsequent years over a 10year period (in some cases extended to 15 years) were granted for the purpose of keeping rents affordable (see Figure 10). New commitments were ended in 1978; over 122000 rental units were produced under
ARP between 1975 and 1980. However, in 1991, expenditures under ARP surged as defaults mounted on problem loans.

ARP was followed in 1981 by the Canada Rental Supply Plan (CRSP) under which sponsors of eligible projects could obtain 15 -year interest-free loans of up to $\$ 7500$ per rental unit constructed. Loans were to be repaid over 25 years. Over 24,000 rental units were built under CRSP across Canada before termination in 1984 (see Figure 10).

The Municipal Incentives Grant (MIG) programme, introduced in 1975, took a different approach to the subsidisation of lowincome housing. This federal programme encouraged the development of land for housing of moderate size, price and density by offering municipalities $\$ 1000$ for each qualifying unit built. The programme terminated in 1978, with payments extended to 1982.

These housing programmes were designed to elicit response in markets for rental housing. The LD and Rental Insurance Plans were designed to reduce risks for investors. ARP and CRSP were intended to reduce effective interest costs and thus spur construction at a time of high interest rates, and MIG was a carrot to make affordable housing more attractive to municipal governments. At the same time, each of these programmes represented a dabbling by governments small in scale and sporadic over time- that never answered the question of why and how much government should be subsidising rental accommodation.

\section{Regulation: Rent Control and Security of Tenure}

In 1940, rent control was introduced by the federal Wartime Prices and Trade Board. Soon after the war, rent control was dismantled and, for the next 25 years, residential rents in the private sector elsewhere went largely unregulated. In 1974, a rentalsman was introduced (abolished in 1985) in British Columbia to mediate landlord-tenant disputes and review large 
rent increases. Then, in 1975, with the introduction of federal wage and price controls, rent regulation was established in each province and territory. Wage and price controls were a temporary measure to control inflation, and were abandoned soon thereafter. However, rent regulation to date has been abandoned only in British Columbia, Alberta, Saskatchewan and New Brunswick.

In Ontario, tinkering with rent control has continued to the presentday: see Arnott and Mintz, 1987; Fallis and Smith, 1985; Fallis, 1985; Miron and Cullingworth, 1983; and Smith and Tomlinson, 1981. Rent regulation was initiated under the Residential Premises Rent Review Act (RPRRA) of 1975. Rent regulation took the form of a review of rent increases for dwellings covered by the legislation. Three provisions were made for rent increases: guideline increase, cost passthrough, and financial loss. Initially, the legislation applied only to rental dwellings in existence prior to 1976. In 1979, RPRRA was replaced by the Residential Tenancies Act (RTA), with a lower guideline rate of increase. In 1982, Ontario passed the Residential Complexes Financing Costs Restraint Act of 1982, which limited the rent increases obtainable through financial loss. In 1986, RTA was repealed and replaced by the Rent Regulation Act (RRA). Guideline rates of increase were then set annually by a formula related to changes in costs of maintaining rental buildings. Guideline rates for the first time applied to the 'maximum rent'; actual rent may be lower, although the initial maximum rent was the existing rent for rental dwellings in use at enactment, or first rent paid since for newer (or other) dwellings. A rent directory was introduced under RRA to record rents for individual apartments, and rent regulation was extended to rental dwellings built since 1976.

The government of Ontario struck a Commission of Inquiry into Residential Tenancies (the Thom Commission). The second volume of that Report, published in 1987, argues that Ontario's scheme of rent regulation should be revoked, that landlords should be able to charge fair market rents, and that tenants who are unable to afford such rents be subsidised. However, that advice was ignored. The RRA was amended in 1991 and replaced by the Rent Control Act (RCA) in 1992. RCA exempts new rental housing from rent control for a period of 5 years. RCA also carefully limits the kind of capital expenditure for which landlords can seek rent increases, permits tenants to apply for a rent reduction even in the absence of a rent increase by the landlord, and increases the policing of landlords to ensure compliance.

Since 1945, there have also been substantial changes to landlord-tenant legislation. In 1969, the Ontario Landlord and Tenant Act (LTA) was proclaimed, taking precedence over any lease agreement. In most residential tenancies, the landlord can evict only with a court order. Grounds for eviction are restricted. Upon termination, residential tenancies automatically renew on a monthly basis under LTA unless a new lease is signed. Tenants can sub-let. Landlords may neither seize contents, nor change locks to the premises. In general, landlords cannot enter a tenant's living quarters without permission or advance notice. Landlords must maintain property in good repair. Landlords are limited to a month's rent as a security deposit; and must pay interest on the latter. Where, at end of tenancy, landlord and tenant disagree about the amount of the damage deposit to be retained by the landlord, court approval must be obtained.

In 1974 , to deal with the loss of rental units resulting from condominium conversions, British Columbia became the first province to give municipalities the ability to stop the conversion of rental units. In 1980, the City of Toronto rezoned every site in the City that contained apartment buildings 20 years of age or older to make redevelopment unprofitable. In 1986, the province of Ontario passed the Rental Housing Protection Act (RHPA) to restrict landlords from converting rental accommodation to other uses. 
What Can Be Learned from the Canadian Experience?

This paper has served two functions. One was to lay out a theoretical perspective in which the Canadian experience can be seen as market outcomes, and to show that this perspective is useful in systematically examining the supply, demand and policy factors that have shaped this outcome. The second has been briefly to review policy initiatives in order to show both the wide range of initiatives that have been undertaken and, at the same time, the relatively simplistic (and often short-term) view that these programmes have taken of the complex of housing markets. What can be learned from the Canadian experience?

Liquidity. The risk involved in borrowing long to lend short deters investment in rental housing. Improving the liquidity of markets for rental housing stock and related investment tools helps spread that risk and hence attract investment. Mortgage-based securities, condominium syndications, limited partnerships and head leases are all useful devices for spreading risks. Regulation that reduces liquidity, e.g. that prevent conversions of rental buildings, will be detrimental. Also of benefit in improving liquidity is standardisation of rental buildings: in materials, design and construction.

Federalism and subsidies. The Canadian experience offers insight into the issue of decentralisation of housing policy. Canada's constitution implies that housing falls within the domain of provincial government. However, the provinces have traditionally been reluctant to engage in costly housing programmes of their own, and have generally participated in federal-provincial programmes only when the federal subsidies were large. Why? Would the provinces not allocate their own tax dollars for this purpose in this absence of federal subsidies, even though they are responsible for housing? Why not? Do the provinces not believe that housing is sufficiently important in the policy agenda; that subsidies are the appropriate tool to address the housing problem?

Objectives. Curiously, for all the housing initiatives tried in Canada, the objectives of housing policy have never been clear. Loosely, the principal objective has been to provide decent housing for all Canadians at an affordable price. However, the terms 'decent' and 'affordable' have never been defined in terms that might make housing policy comparable with other aspects of social policy.

Income maintenance. Governments in Canada simultaneously promote income maintenance on the one hand and provide housing subsidies on the other. Do we need both? Can we not provide adequate and affordable housing best by raising incomes among the needy? Of course, there may well be a need for both incomes and housing policies; my point here is simply that Canadian governments have not clarified how the objectives of housing policy differ from income maintenance.

The small investor. The small investor has always been important in the supply of rental housing. The attractiveness of rental housing to such investors is sensitive to the rules governing taxation of rental income. The Canadian experience suggests how important it is for governments to be careful in the details of such taxation (depreciation allowances, soft costs, rental losses, capital gains and recapture) in order to avoid sudden changes in the rate of investment in rental housing stock.

\section{Notes}

1. In Canadian Censuses, a private household is the person, or set of persons, living in a private dwelling. The latter is a set of structurally separate living quarters with its own private entrance. Private dwellings exclude accommodation in collective buildings.

2. In all Censuses since 1941, a household is deemed to rent its dwelling if no member of the household owns it. In the 1951 Census only, a dwelling was owner-occupied only if 
owned by the head of household of a member of the immediate family. In all these Censuses, the dwelling is deemed to be owned even if (1) there is an outstand ing mortgage or other lien on the property; (2) it is situated on rented or leased land; or (3) it is a condominium unit. Other dwellings are deemed to be rented even if no rent is paid. Persons living in continuing housing cooperatives, whether equity or non-equity, are deemed to be renters.

3. The conventional rental stock consists of dwellings in apartment blocks and row-housing projects that are designed and built to be rented. The non-conventional rental stock consists of single detached dwellings, flats carved out of former single detached dwellings, and apartments in condominium buildings, and other buildings that were built to be owner-occupied. Steele (1993) discusses the growing importance of the nonconventional rental stock in Canada.

4. These counts include households that rent publicly assisted, non-institutional housing; these are commonly thought to be not more than 6 per cent of the total stock of private dwellings.

5. This estimate overstates the yield to a landlord since it ignores the value of the land asset on which the rental building is standing. This estimate also ignores the effect of resale value of the building on economic return to a landlord.

6. As defined in the Canadian census, a family is a husband-wife couple plus any co-resident never-married children (regardless of age), or a lone parent living with one or more never-married children; anyone else is a nonfamily person.

7. For a description of kinds of Canadian homeowners who live in condominiums, see Meligrana (1993).

8. A split between these roles is evidenced in the use of 'head' leases. In a head lease, an entrepreneurial property manager purchases from the investor the right to rent out dwellings in the building. The property manager pays an annual fee to the investor and earns income from the difference between the fee and the rents collected. The head lease typically also specifies maintenance to be undertaken by the property manager.

9. The federal government has also introduced commodity taxation, first the Federal Sales Tax (FST) and later the Goods and Services Tax (GST), with respect to housing construction. See Smith (1991) for further discussion of the implications of the GST for real estate markets.

10. In 1985 , the federal government introduced a lifetime cumulative capital gains exemption: initially to be $\$ 500000$, the exemption was capped at $\$ 100000$ in 1987 . However, this incentive to invest in assets (including rental housing) was offset when the capital gains inclusion rate was raised to $66_{3}^{2}$ per cent in 1988, then 75 per cent in 1990. As well, Cumulative Net Investment Loss (CNIL) tax rules, introduced in 1988, limit the net capital gains that can be tax-sheltered by the capital gains exemption.

\section{References}

Arnault, E.J. (1975) Optimal maintenance under rent control with quality constraints, American Real Estate and Urban Economics Association Journal, 3(2), pp. 67-82.

Arnott, R.J. and Mintz, J.M. (1987) Policy Forum on Rent Controls in Ontario. Kingston, Ontario: John Deutsch Institute for the Study of Economic Policy, Queen's University.

Clayton Research Associates Limited (1991) Rental Housing: A Study of Selected Local Markets. Canada Mortgage and Housing Corporation.

FALLIS, G. (1985) Rent control in Toronto: tenant rationing and tenant benefits, Canadian Public Policy, 11(3), pp. 543-550.

Fallis, G. (1993) The suppliers of housing, in: J.R. Miron (Ed.) House, Home, and Community: Progress in Housing Canadians, 19451986, pp. 76-93. Montreal: McGill-Queen's University Press.

Fallis, G. and Smith, L.B. (1985) Price effects of rent control on controlled and uncontrolled rental housing in Toronto: a hedonic index approach, Canadian Journal of Economics, 18(3), pp. 652-659.

Firestone, O.J. (1951) Residential Real Estate in Canada. Toronto: University of Toronto Press.

GUASCH, J.L. and MARSHALl, R.C. (1987) A theoretical and empirical analysis of the length of residency discount in the rental housing market, Journal of Urban Economics, 22, pp. 291-311.

Kanemoto, Y. (1990) Contract types in the property market, Regional Science and Urban Economics, 20(1), pp. 5-22.

MCKellar, J. (1993) Building technology and the production process, in: J.R. MIRON (Ed.) House, Home, and Community: Progress in Housing Canadians, 1945-1986, pp. 136-154. Montréal: McGill-Queen's University Press.

Meligrana, J. (1993) Exercising the condominium tenure option: a case study of the Canadian housing market, Environment and Planning A, 25, pp. 961-973. 
MiCELI, T.J. (1989) Housing rental contracts and adverse selection with an application to the rent-own decision, American Real Estate and Urban Economics Association Journal, 17(4), pp. 403-421.

Miron, J.R. (1988) Housing in Postwar Canada. Kingston and Montreal: McGill-Queen's University Press.

Miron, J.R. (1990) Security of tenure, costly tenants, and rent regulation, Urban Studies, 27, pp. $167-184$.

Miron, J.R. and Cullingworth, J.B. (1983) Rent Control: Impacts on Income Distribution, Affordability, and Security of Tenure. Toronto: Centre for Urban and Community Studies, University of Toronto.

OlsEn, E.O. (1987) The demand and supply of housing service: a critical survey of the empirical literature, in: E.S. MiLls (Ed.) Handbook of Regional and Urban Economics, pp. 989-1022. Amsterdam: Elsevier Science Publishers.

PoAPsT, J.V. (1993) Financing of post-war housing, in: J.R. MIRON (Ed.) House, Home, and Community: Progress in Housing Canadians, 1945-1986, pp. 94-109. Montréal: McGillQueen's University Press.

Quigley, J.M. (1979) What have we learned about urban housing markets, in: $P$. MieszKowski and M. STRASZheim (Eds) Current Issues in Urban Economics, pp. 391-429. Baltimore: Johns Hopkins University Press.

Rose, A. (1980) Canadian Housing Policies: 1935-1980. Toronto: Butterworths.

RudeL, T.K. (1987) Housing price inflation, family growth, and the move from rented to owner occupied housing, Urban Studies, 24, pp. 258-267.

Smith, L.B. (1981) Canadian housing policy in the seventies, Land Economics, 57(3), pp. 338352.

Smith, L.B. (1983) The crisis in rental housing: a Canadian perspective, Annals of the American Association of Political and Social Sciences, 465, pp. 58-75.

Smith, L.B. (1991) Implications of the Canadian Goods and Services Tax for real estate markets, Journal of Housing Economics, 1, pp. 75-89.

Smith, L.B., Rosen, K.T. and Fallis, G. (1988) Recent developments in economic models of housing markets, Journal of Economic Literature, 26(1), pp. 29-64.

Smith, L.B. and Tomlinson, P. (1981) Rent control in Ontario: roofs or ceilings? American Real Estate and Urban Economics Association Journal, 9, pp. 93-114.

Steele, M. (1993) Conversions, condominiums and capital gains: the transformation of the Ontario rental housing market, Urban Studies, 30, pp. 103-126.

Stull, W.J. (1978) The landlord's dilemma: asking rent strategies in a heterogeneous housing market, Journal of Urban Economics, 5(1), pp. 101-115.

SWEENEY, J. (1974) A commodity hierarchy model of the rental housing market, Journal of Urban Economics, 1, pp. 288-323.

Weber, S. and Wiesmeth, H. (1990) Equilibria in a market with state-contingent rental contracts, Regional Science and Urban Economics, 20, pp. 23-41. 
Copyright of Urban Studies is the property of Carfax Publishing Company and its content may not be copied or emailed to multiple sites or posted to a listserv without the copyright holder's express written permission. However, users may print, download, or email articles for individual use. 